\title{
Commentary Variation in breast cancer risk in BRCA1 and BRCA2 mutation carriers
}

\author{
Timothy R Rebbeck and Susan M Domchek
}

Center for Clinical Epidemiology and Biostatistics and Abramson Cancer Center, University of Pennsylvania, Philadelphia, PA 19104, USA

Corresponding author: Timothy R Rebbeck, rebbeck@mail.med.upenn.edu

Published: 25 July 2008

This article is online at http://breast-cancer-research.com/content/10/4/108

(c) 2008 BioMed Central Ltd
Breast Cancer Research 2008, 10:108 (doi:10.1186/bcr2115)

breast cancer. For example, Lee and colleagues [6] examined the lifetime risk of cancer in first-degree relatives (FDRs) of $B R C A 1 / 2$ mutation carriers with breast or ovarian cancers. The standardized incidence ratio for breast cancer was 10.6 (95\% confidence interval 5.2 to 21.6 ) in FDRs of breast cancer probands and 3.3 (1.4 to 7.5) in FDRs of ovarian cancer probands $(p=0.02)$. Similarly, the standardized incidence ratio for ovarian cancer was 7.9 (1.2 to 5.3) for FDRs of breast cancer probands, and 11.3 (3.6 to 31.9) for FDRs of ovarian cancer probands, although this difference was not statistically significant $(p=0.37)$. Why should this be? Phenotype-genotype correlations of specific gene mutations exist that suggest that some mutations are more likely to confer risk of ovarian cancer versus breast cancer $[7,8]$. However, it is not likely that such genotype-phenotype association is sufficient to explain the wide ranges of risks that have been observed. Thus, exposures or genes at other loci may also modify risk.

\section{Exposures}

Factors including parity, age at menarche and first birth, duration of breast feeding, mammographic density, exogenous hormone exposures, and dietary factors, including alcohol intake, are known to impact breast cancer risk in the general population (reviewed in [9-13]). These factors may also cluster in families. The impact of reproductive factors on breast cancer risk in $B R C A 1 / 2$ mutation carriers is largely unresolved, although recent large-scale studies have reported that exogenous hormone exposures (for example, oral contraceptives) and reproductive history may alter breast cancer risk [14-17]. Other environmental exposures have been investigated among BRCA1/2 mutation carriers, including cigarette smoking and caffeine intake, but results have been inconsistent [18-21].

Medical interventions, such as risk-reducing salpingooophorectomy (RRSO), have also been demonstrated to

FDR $=$ first-degree relative; RRSO = risk-reducing salpingo-oophorectomy. 
decrease breast and ovarian cancer risk, but are often not considered in studies estimating penetrance [22,23]. Since it has been observed that use of RRSO varies by population [24], difference in risk estimates may also be affected by variable use of these preventive options.

Finally, variability in cancer risks have been reported by year of birth [5], suggesting that changes in reproductive history, exposures or other risk factors that vary by birth cohort may influence cancer risks [5]. While it is not clear whether these effects are due to true cancer risk modification rather than selection biases, birth cohort effects could have influenced cancer risks and risks in different reports.

\section{Modifier genes}

There is increasing evidence that genetic modifiers of $B R C A 1 / 2$ risk exist. The most clear-cut is modification of $B R C A 2$-associated breast cancer risk by RAD51 [25], but other genes, including FGFR2, TNRC9, AURKA, and $M A P 3 K 1$ [26-28], have been suggested as risk modifiers. Although their effects are quite modest, interactions of genotypes with exposures, birth cohort effects, reproductive factors, and interventions such as RRSO may provide significant information about risk.

\section{The Begg study}

Begg and colleagues [29] examined cancer risks using 2,098 women diagnosed with breast cancer between 1985 and 2000 (1,394 with unilateral breast cancer, 704 with bilateral breast cancer) who participated in the Women's Environmental Cancer and Radiation Epidemiology (WECARE) study. A total of 109 BRCA1 and 72 BRCA2 mutation carriers were identified. Cancer risks were estimated for FDRs of these women. The study found risk estimates significantly lower than in studies of high-risk families [1], with a cumulative risk of breast cancer to age 70 of $36 \%$ to $48 \%$ for $B R C A 1$ carriers, and $47 \%$ to $59 \%$ for BRCA2 carriers. Increased risk was associated with a younger age of the proband, and a trend toward increased risk was seen for relatives of probands with bilateral versus unilateral breast cancer.

Despite the useful information provided by this research, there are several considerations to be made in interpreting this study. Despite the large population based sample, only 181 mutation carriers were identified (with 598 FDRs, of whom 50\% were estimated to be mutation carriers), thus limiting the power to estimate cumulative risks. A very large number of BRCA1/2 mutation carriers, 58\%, had no FDR affected with breast cancer; however, several reasons based on the design of the study may account for this. First, only FDRs were examined and thus breast cancer in the paternal linage was not considered. Information is not given on the percentage of probands with no sisters or daughters, a fact particularly relevant in those with a mutation inherited from the paternal lineage. It is not known if probands or their FDRs were aware of their mutation status and, if so, what prophylactic measures might have been taken, such as mastectomy or oophorectomy. Both of these interventions would significantly alter cancer risk. Ovarian cancer was not considered as an endpoint. The study population was uniquely selected as patients were eligible only if they had node negative breast cancer diagnosed under the age of 55 between 1985 and 2000, and then were recruited between 2000 and 2004. Therefore, survival and other biases may exist. Finally, the authors did not consider potential birth cohort effects, which have been identified in multiple studies and may have influenced some results.

The major limitation in making clinical inferences from this study, however, is that the sample studied by Begg and colleagues may not represent the women who currently undergo genetic testing. Individuals without a significant family history are not recommended to have genetic testing [30] and this population will not have routine insurance coverage for genetic testing. Thus, the clinical implications of Begg and colleagues (and other studies of this type) are limited by sampling/design issues.

\section{What do we need to know before changing clinical recommendations?}

Individualized risk assessment is the holy grail of the human genome - not only for BRCA1/2 mutation carriers but for the general population. Such assessment may be possible: proband cancer type matters, evidence for genotypephenotype correlations exist; there is evidence for modifier genes. However, the most important question is whether decision-making will change when this information is available. Will we ever feel comfortable telling a mutation carrier that she does not need RRSO, particularly if we continue to have no effective ovarian cancer screening strategy? Will physicians ever insist on prophylactic mastectomy? Will women make different decisions based on a $40 \%$ lifetime risk of breast cancer versus a $60 \%$ lifetime risk? These and many other unanswered questions remain even as we strive for improved risk estimation and stratification.

\section{Competing interests}

The authors declare that they have no competing interests.

\section{References}

1. Easton DF, Ford D, Bishop DT: Breast and ovarian cancer incidence in BRCA1-mutation carriers. Breast Cancer Linkage Consortium. Am J Hum Genet 1995, 56:265-271.

2. Fodor FH, Weston A, Bleiweiss IJ, McCurdy LD, Walsh MM, Tartter PI, Brower ST, Eng CM: Frequency and carrier risk associated with common BRCA1 and BRCA2 mutations in Ashkenazi Jewish breast cancer patients. Am J Hum Genet 1998, 63:45-51.

3. Hopper JL, Southey MC, Dite GS, Jolley DJ, Giles GG, McCredie $M R$, Easton DF, Venter DJ: Population-based estimate of the average age-specific cumulative risk of breast cancer for a defined set of protein-truncating mutations in BRCA1 and BRCA2. Australian Breast Cancer Family Study. Cancer Epidemiol Biomarkers Prev 1999, 8:741-747.

4. Brose MS, Rebbeck TR, Calzone KA, Stopfer JE, Nathanson KL, 
Weber BL: Cancer risk estimates for BRCA1 mutation carriers identified in a risk evaluation program. I Natl Cancer Inst 2002, 94:1365-1372.

5. King MC, Marks JH, Mandell JB: Breast and ovarian cancer risks due to inherited mutations in BRCA1 and BRCA2. Science 2003, 302:643-646.

6. Lee JS, John EM, McGuire V, Felberg A, Ostrow KL, DiCioccio RA, Li FP, Miron A, West DW, Whittemore AS: Breast and ovarian cancer in relatives of cancer patients, with and without BRCA mutations. Cancer Epidemiol Biomarkers Prev 2006, 15:359-363.

7. Gayther SA, Mangion J, Russell P, Seal S, Barfoot R, Ponder BA, Stratton MR, Easton D: Variation of risks of breast and ovarian cancer associated with different germline mutations of the BRCA2 gene. Nat Genet 1997, 15:103-105.

8. Gayther SA, Warren W, Mazoyer S, Russell PA, Harrington PA, Chiano M, Seal S, Hamoudi R, van Rensburg EJ, Dunning AM, Love R, Evans G, Easton D, Clayton D, Stratton MR, Ponder BA: Germline mutations of the BRCA1 gene in breast and ovarian cancer families provide evidence for a genotype-phenotype correlation. Nat Genet 1995, 11:428-433.

9. Tjønneland A, Christensen J, Olsen A, Stripp C, Thomsen BL, Overvad K, Peeters $\mathrm{PH}$, van Gils $\mathrm{CH}$, Bueno-de-Mesquita $\mathrm{HB}$, Ocké MC, Thiebaut A, Fournier A, Clavel-Chapelon F, Berrino F, Palli D, Tumino R, Panico S, Vineis $P$, Agudo A, Ardanaz E, Martinez-Garcia C, Amiano P, Navarro C, Quirós JR, Key TJ, Reeves G, Khaw KT, Bingham S, Trichopoulou A, Trichopoulos D, et al.: Alcohol intake and breast cancer risk: the European Prospective Investigation into Cancer and Nutrition (EPIC). Cancer Causes Control 2007, 18:361-373.

10. Vachon CM, van Gils $\mathrm{CH}$, Sellers TA, Ghosh K, Pruthi S, Brandt $\mathrm{KR}$, Pankratz VS: Mammographic density, breast cancer risk and risk prediction. Breast Cancer Res 2007, 9:217.

11. Kiley J, Hammond C: Combined oral contraceptives: a comprehensive review. Clin Obstet Gynecol 2007, 50:868-877.

12. Troisi R, Potischman N, Hoover RN: Exploring the underlying hormonal mechanisms of prenatal risk factors for breast cancer: a review and commentary. Cancer Epidemiol Biomarkers Prev 2007, 16:1700-1712.

13. Michels KB, Mohllajee AP, Roset-Bahmanyar E, Beehler GP, Moysich KB: Diet and breast cancer: a review of the prospective observational studies. Cancer 2007, 109:2712-2749.

14. Brohet RM, Goldgar DE, Easton DF, Antoniou AC, Andrieu N, Chang-Claude J, Peock S, Eeles RA, Cook M, Chu C, Noguès C, Lasset $\mathrm{C}$, Berthet $\mathrm{P}$, Meijers-Heijboer $\mathrm{H}$, Gerdes AM, Olsson $\mathrm{H}$, Caldes T, van Leeuwen FE, Rookus MA: Oral contraceptives and breast cancer risk in the international $B R C A 1 / 2$ carrier cohort study: a report from EMBRACE, GENEPSO, GEO-HEBON, and the IBCCS collaborating group. J Clin Oncol 2007, 25:38313836

15. Chang-Claude J, Andrieu N, Rookus M, Brohet R, Antoniou AC, Peock S, Davidson R, Izatt L, Cole T, Nogues C, Luporsi E, Huiart L, Hoogerbrugge N, Van Leeuwen FE, Osorio A, Eyfjord J, Radice P, Goldgar DE, Easton DF; Epidemiological Study of Familial Breast Cancer (EMBRACE); Gene Etude Prospective Sein Ovaire (GENEPSO); Genen Omgeving studie van de werkgroep Hereditiair Borstkanker Onderzoek Nederland (GEO-HEBON); International BRCA1/2 Carrier Cohort Study (IBCCS) collaborators group: Age at menarche and menopause and breast cancer risk in the International BRCA1/2 Carrier Cohort Study. Cancer Epidemiol Biomarkers Prev 2007, 16:740-746.

16. Andrieu N, Goldgar DE, Easton DF, Rookus M, Brohet R, Antoniou AC, Peock S, Evans G, Eccles D, Douglas F, Noguès $C$, Gauthier-Villars M, Chompret A, Van Leeuwen FE, Kluiit I, Benitez J, Arver B, Olah E, Chang-Claude J; EMBRACE; GENEPSO; GEO-HEBON; IBCCS Collaborators Group: Pregnancies, breast-feeding, and breast cancer risk in the International BRCA1/2 Carrier Cohort Study (IBCCS). J Natl Cancer Inst 2006, 98:535-544

17. Antoniou AC, Shenton A, Maher ER, Watson E, Woodward E, Lalloo F, Easton DF, Evans DG: Parity and breast cancer risk among BRCA1 and BRCA2 mutation carriers. Breast Cancer Res 2006, 8:R72.

18. Colilla S, Kantoff PW, Neuhausen SL, Godwin AK, Daly MB, Narod SA, Garber JE, Lynch HT, Brown M, Weber BL, Rebbeck TR: The joint effect of smoking and AIB1 on breast cancer risk in BRCA1 mutation carriers. Carcinogenesis 2006, 27:599-605.
19. Ghadirian $P$, Lubinski J, Lynch $H$, Neuhausen $S L$, Weber $B$, Isaacs C, Baruch RG, Randall S, Ainsworth P, Friedman E, Horsman D, Tonin P, Foulkes WD, Tung N, Sun P, Narod SA: Smoking and the risk of breast cancer among carriers of BRCA mutations. Int J Cancer 2004, 110:413-416.

20. Brunet JS, Ghadirian P, Rebbeck TR, Lerman C, Garber JE, Tonin PN, Abrahamson J, Foulkes WD, Daly M, Wagner-Costalas J, Godwin A, Olopade OI, Moslehi R, Liede A, Futreal PA, Weber BL, Lenoir GM, Lynch HT, Narod SA: Effect of smoking on breast cancer in carriers of mutant BRCA1 or BRCA2 genes. $J$ Natl Cancer Inst 1998, 90:761-766.

21. Nkondjock $A$, Ghadirian $P$, Kotsopoulos J, Lubinski J, Lynch $H$, Kim-Sing C, Horsman D, Rosen B, Isaacs C, Weber B, Foulkes W, Ainsworth P, Tung N, Eisen A, Friedman E, Eng C, Sun P, Narod SA: Coffee consumption and breast cancer risk among BRCA1 and BRCA2 mutation carriers. Int J Cancer 2006, 118: 103-107.

22. Rebbeck TR, Lynch HT, Neuhausen SL, Narod SA, Van't Veer L, Garber JE, Evans G, Isaacs C, Daly MB, Matloff E, Olopade OI, Weber BL; Prevention and Observation of Surgical End Points Study Group: Prophylactic oophorectomy in carriers of BRCA1 or BRCA2 mutations.[see comment]. New Eng J Med 2002, 346:1616-1622.

23. Kramer JL, Velazquez IA, Chen BE, Rosenberg PS, Struewing JP, Greene $\mathrm{MH}$ : Prophylactic oophorectomy reduces breast cancer penetrance during prospective, long-term follow-up of BRCA1 mutation carriers. J Clin Oncol 2005, 23:8629-8635.

24. Friebel TM, Domchek SM, Neuhausen SL, Wagner T, Evans DG, Isaacs C, Garber JE, Daly MB, Eeles R, Matloff E, Tomlinson G, Lynch HT, Tung N, Blum JL, Weitzel J, Rubinstein WS, Ganz PA, Couch F, Rebbeck TR: Bilateral prophylactic oophorectomy and bilateral prophylactic mastectomy in a prospective cohort of unaffected BRCA1 and BRCA2 mutation carriers. Clin Breast Cancer 2007, 7:875-882.

25. Antoniou AC, Sinilnikova OM, Simard J, Leone M, Dumont M, Neuhausen SL, Struewing JP, Stoppa-Lyonnet D, Barihoux L, Hughes DJ, Coupier I, Belotti M, Lasset C, Bonadona V, Bignon YJ; Genetic Modifiers of Cancer Risk in BRCA1/2 Mutation Carriers Study (GEMO), Rebbeck TR, Wagner T, Lynch HT, Domchek SM, Nathanson KL, Garber JE, Weitzel J, Narod SA, Tomlinson G, Olopade OI, Godwin A, Isaacs C, Jakubowska A, Lubinski J: RAD51 135G->C modifies breast cancer risk among BRCA2 mutation carriers: results from a combined analysis of 19 studies. Am J Hum Genet 2007, 81:1186-1200.

26. Rebbeck TR, Wang Y, Kantoff PW, Krithivas K, Neuhausen SL, Godwin AK, Daly MB, Narod SA, Brunet JS, Vesprini D, Garber JE, Lynch HT, Weber BL, Brown M: Modification of BRCA1- and BRCA2-associated breast cancer risk by AIB1 genotype and reproductive history. Cancer Research 2001, 61:5420-5424.

27. Antoniou AC, Spurdle AB, Sinilnikova OM, Healey S, Pooley KA Schmutzler RK, Versmold B, Engel C, Meindl A, Arnold N, Hofmann W, Sutter C, Niederacher D, Deissler H, Caldes T, Kämpjärvi K, Nevanlinna H, Simard J, Beesley J, Chen X; Kathleen Cuningham Consortium for Research into Familial Breast Cancer, Neuhausen SL, Rebbeck TR, Wagner T, Lynch HT, Isaacs C Weitzel J, Ganz PA, Daly MB, Tomlinson G, Olopade OI: Common breast cancer-predisposition alleles are associated with breast cancer risk in BRCA1 and BRCA2 mutation carriers. Am J Hum Genet 2008, 82:937-948.

28. Couch FJ, Sinilnikova O, Vierkant RA, Pankratz VS, Fredericksen ZS, Stoppa-Lyonnet D, Coupier I, Hughes D, Hardouin A, Berthet P, Peock S, Cook M, Baynes C, Hodgson S, Morrison PJ, Porteous ME, Jakubowska A, Lubinski J, Gronwald J, Spurdle AB; kConFab, Schmutzler R, Versmold B, Engel C, Meindl A, Sutter C Horst J, Schaefer D, Offit K: AURKA F31I Polymorphism and Breast Cancer Risk in BRCA1 and BRCA2 Mutation Carriers: A Consortium of Investigators of Modifiers of BRCA1/2 Study. Cancer Epidemiol Biomarkers Prev 2007, 16:1416-1421.

29. Begg CB, Haile RW, Borg A, Malone KE, Concannon $P$, Thomas DC, Langholz B, Bernstein L, Olsen JH, Lynch CF, Anton-Culver H, Capanu M, Liang X, Hummer AJ, Sima C, Bernstein JL: Variation of breast cancer risk among BRCA1/2 carriers. JAMA 2008, 299:194-201.

30. US Preventive Serivces Task Force: Genetic risk assessment and BRCA mutation testing: recommendation statement. Ann Internal Med 2005, 143:355-361. 